\title{
Estimating Food Demand System and Rural Household Welfare: A Case Study from Pakistan
}

\author{
Lubna Naz ${ }^{1}$ Munir Ahmad², G.M.Arif ${ }^{3}$
}

\begin{abstract}
This article adds to the existing literature by analyzing static and dynamic welfare impacts of food price changes for rural households in Pakistan. All three waves of Pakistan Rural Household Survey (2001, 2004, and 2010) were used. Lagrange Multiplier and a test of the coefficients of squared expenditure term (Likelihood Ratio test) were used to determine whether QUAIDS is an appropriate model or not. Nonlinear Seemingly Unrelated Regression (NLSUR) was used to estimate demand functions for eight food groups (Cereals, milk, and milk products, vegetables, cooking oil, pulses and other food). Results indicate inelastic expenditure elasticity of cereals in the pooled sample. Own price elasticities for all food groups, except other food, are smaller than zero during the entire sampled period $(2001,2004,2010)$, and cereals are complimentary with meat and pulses, as suggested by cross price elasticities (uncompensated). Furthermore, results reveal that rural households needed a 28 percent increase in food expenditure and 26 percent increase in total expenditure to return to the previous level of welfare (year-2001).
\end{abstract}

Keywords: Cross-Price Elasticity, Lagrange Multiplier, Nonlinear Seemingly Unrelated Regression, Own-Price Elasticity.

JEL Classification: C51, D11, I31

\section{Introduction}

Existing literature generally deals with the econometric modeling of the relationship between total expenditures and budget shares of goods. The models include Linear Expenditure System (LES) of (Stone, 1954), Rotterdam Model of (Barten, 1964) and (Theil, 1965), Translog model proposed by (Christensen, Jorgenson, \& Lau, 1975) and (Jorgenson \& Slesnick, 1987), AIDS model of (Deaton \& Muellbauer, 1980), and QUAIDS proposed by (Banks, Blundell, \& Lewbel, 1997).

LES assumes a linear relationship between total expenditures and food share

1 Ph.D. Candidate at Pakistan Institute of Development Economics Islamabad.

2 Joint Director PIDE, Islamabad

3 Joint Director PIDE, Islamabad

\section{ARTICLE HISTORY}

21 Oct, 2018 Submission Received

10 Nov, 2018 First Review

20 Nov, 2018 Second Review

28 Nov, 2018 Third Review

8 Dec, 2018 Accepted 
while ignoring the possibility of a non-linearity important feature of the Engel's Law. Translog model has budget shares that are a linear function of log total expenditure, which are not consistent with utility-maximizing behavior because it does not involve a specific functional form of utility or cost. Unlike Translog, the AIDS model assumes linearity in the relationship of log total expenditures and budget shares and is consistent with the utility maximizing behavior of the households. It is a QUAIDS model that assumes some of the budget shares (or not all budget shares) show a nonlinear relationship with total expenditures.

In Pakistan, the current literature mainly lacks in the use of the panel data, which encapsulates variability and heterogeneity aspects of food consumption pattern simultaneously, for modeling food demand. (Siddiqui, 1982) used the single equation to measure expenditure elasticities for food and non-food groups. The main drawback of Single Equation Model is its inability to comply with the adding up property of the demand system. (Ali, 1985), and (Ahmad, Ludlow, \& Stern, 1988) used the Extended Linear Expenditure System (ELES) to compute estimates for consumer expenditures. ELES complies with all properties of the demand system (adding up, symmetry, homogeneity) and is consistent with utility maximization principle of the demand system. However, the problem rests with two main implications of LES; goods cannot be inferior, and all goods are substitutes.

Studies by (Alderman, 1988) and (Burki, 1997) used time series and pooled cross-sectional data to estimate price and expenditure elasticities for rural and urban households. They used the Almost Ideal Demand System proposed by (Deaton \& Muellbauer, 1980). (Haq, Nazli, \& Meilke, 2008) used Linear Approximate Almost Ideal Demand System ( LA-AIDS) and included scale effect into the demand analysis for calculating own price, cross price, and expenditure elasticities. The main drawback of AIDS and LA-AIDS demand systems is the underlying assumption of a linear relationship between total household expenditure and budget shares. Only a few studies by (Kurosaki, 2006) and (McCulloch \& Baulch, 2000) used of panel data. Nevertheless, these studies have analyzed only dynamics of poverty and vulnerability for selected rural households and used limited panel data sets (not regionally and nationally representative).

All studies (in the context of Pakistan) used parametric approaches for specifying food demand system. Only (Bhalotra \& Attfield, 1998) used the semiparametric method. They specified rank-three or Quadratic Almost Ideal Demand System (QUAIDS) of food for rural households of Pakistan. However, their analysis used the cross-sectional data set (HIES, 1986-87).

(Haq \& Cranfield, 2011) followed Generalized-Barten to model preferences of 
food using cross-sectional data set (HIES, 2005) for rural and urban households. This indicates improvement in the earlier research work in the choice of demand system (as different versions of the Rotterdam model are nested Generalized Barten) to measure expenditure and price elasticities. The only limitation of their analysis was the use of cross-sectional data that cannot reveal variability in food consumption over time.

Recently, a study by (Hayat, Hussain, \& Yousaf, 2016) analyzed food demand system (LA-AIDS) and estimated projections of the selected food groups from 2010 to 2030. Authors used the Pakistan Panel Household Survey (2010), GDP growth data (2010-2030) and macroeconomic data (2005). Their study concludes that food grain, vegetables, and pulses are necessary goods and milk and meat are luxuries. Size of the household affects consumption of milk negatively; it relates to other food positively. Results from projection analysis suggest double increase (in between 2010 and 2030) in a per capita and total household demand for food grain, pulses, and vegetables. However, their study used restrictive assumptions (constant price, fixed population growth rate, and no change in taste and technology) to undertake projection analysis.

The survey of the literature indicates that no study has so far specified the rank of food demand system for the panel rural households in Pakistan. The identification of the rank of food demand system is necessary for two important reasons. First, the higher rank demand system (for example, QUAIDS) allows the possibility of becoming a necessity to luxury or luxury of becoming a necessity at different levels of real expenditures, moving from lower to higher or vice versa (Banks et al., 1997). Second, the correctly specified functional form of the demand system plays an important role in household welfare analysis; it helps in measuring the robust estimates of expenditure and price elasticities to be used in the calculation of the real gain or loss in household's welfare.

Only two studies have provided estimates of the welfare effects of food price changes in Pakistan at the aggregate level. (Friedman, Hong, \& Hou, 2011) used repeated cross-sectional data (2005-06, 2007-08 and 2010 (January-June)) and estimated compensation variation for rural and urban households. Their study did not use theoretically consistent demand model and did not include results for the welfare impact of food prices with the substitution effect. Results indicate that rural and urban households needed 39.1 percent and 36 percent increase in income (without substitution effect), respectively, to maintain utility at the pre-crisis level (2005-06). (Ul Haq et al., 2008) used cross-sectional data set, HIES (2004-05), and estimated welfare effects of counterfactual price changes for poor and non-poor in urban and rural samples. Authors found that counterfactual food price changes increased the rural poverty by 32.5 percent and the urban poverty by 44.6 percent. 
This background, this paper contributes to the existing literature by analyzing static and dynamic effects of food price and income changes for rural households in Pakistan.

It has twofold objectives. First, unlike earlier studies, we use parametric tests to specify the rank of food demand system for the panel rural households. For this purpose, we use the Lagrange Multiplier test and test of the coefficient of squared expenditure term (termed as Likelihood Ratio test) to determine whether Quadratic Almost Ideal Demand System is an appropriate model or not. The QUAIDS is of rank 3 and exactly aggregable (Lewbel, 1991).

Second, we estimate money metric gain or loss in welfare in the short-term (static) as well as in the medium-term (dynamic). This provides the opportunity to analyze changes in the welfare with and without substitution in food commodities. We use coefficients of expenditure and price elasticities to estimate the welfare gain or loss and Taylor approximation to calculate the proportion of money needed to return the household to its old welfare level (pre-price-change).

The results reveal that food demand system is of rank three in Pakistan. The consumption of cereals constitutes the largest share in the total food expenditures; own price elasticities (uncompensated and compensated) of cereals range $(-0.91$, -0.86), implying directly proportional relationship in between food expenditure and the price of cereals. Static welfare effect, monetary loss emanating from food price changes, tends to be higher than dynamic welfare effect. Moreover, estimates of the welfare impacts by commodity groups suggest that rural households need the highest compensation for changes in cereal prices followed by meat prices, which provokes policymakers to formulate the commodity specific social safety measures.

The rest of the paper is organized as follows, Section 2 discusses sampling methodology and dataset, Section 3 presents a theoretical framework, Section 4 elaborates empirical methods, Section 5 presents results and discussion followed by the conclusion and policy recommendation.

\section{Sampling Methodology and Data}

This Paper used three waves of Pakistan Panel Rural Household Survey, Pakistan Rural Household Survey 2001 or PRHS 1, Pakistan Rural Household Survey 2004 or PRHS 2, and Pakistan Panel Household Survey 2010 or PPHS 3). Pakistan Institute of Development Economics, Islamabad in coordination with the World Bank conducted field surveys for data collection; a two-stage random sampling technique was used. The questionnaire (in all three waves) covered wide-ranging topics: household demographics, education, farm, and non-farm employment, land and livestock ownership, 
food and non-food consumption, housing and assets, health, credit, and transfers.

PRHS 1 and PPHS 3 were conducted in the rural areas of all four provinces; the latter survey was piloted for urban households as well. PRHS 2 was held in the rural areas of Sindh and Punjab; the Khyber Pakhtunkhwa and Baluchistan could not be covered due to poor law and order situation. Therefore, this article mainly covered panel rural households from Sindh and Punjab only. The rural panel households in first two waves were 1,629 (2001-2010) and in last two waves (2004-2010) were 1,331 in Sindh and Punjab. The attrition rate (households who could not be tracked and re-interviewed) between 2001 and 2004 was 11 percent, and between 2001 and 2010 was found 28 percent. The rural panel households in the first two waves (PRHS 1 and PRHS 2) were 1,629 and in the last two waves (PRHS 2 and PPHS 3) were 1,331 in both Sindh and Punjab. The rural panel households of Sindh were 510, and of Punjab were 708 (Arif, 2012). The present study used 3,654 (3x1218) data points for analysis. The data covered in all three waves provided largely information on food purchases and very little or insufficient information was provided on panel household's food production. This paper used only food consumption data of those rural households who were net buyers (only 8 percent of rural households were both buyers and sellers in all rounds).

\section{Theoretical Framework}

The almost ideal demand system (AIDS), given by (Deaton \& Muellbauer, 1980), is a member of the family of Price-Independent Generalized logarithmic (PIGLOG) models. The PIGLOG preferences are derived from indirect utility functions, which are linear in log total expenditures. On the other hand, another strand of demand models allows non-linearity in budget share equations. (Banks et al., 1997a) developed the QUAIDS model, which establishes a nonlinear relationship between budget shares and log total expenditures; the budget shares are quadratic in log total expenditures.

The QUAIDS generalizes PIGLOG preferences, using the indirect utility function, as follows,

$$
\ln V=\left\{\left\lfloor\frac{\ln x-\ln a(p)}{b(p)}\right]^{-1}+\lambda(p)\right\}^{-1}
$$

$x$ denotes total expenditure, $a(p)$ and $b(p)$ are Translog and Cobb Douglas functions of prices, (see AIDS demand model for details on the specification of prices), $\lambda(\mathrm{p})$ takes on the value of zero in the AIDS model. The specific functional forms of $a(p), b(p)$ and $\lambda(p)$ are,

$$
\ln a\left(p_{t}^{h}\right)=\alpha+\sum_{i=1}^{n} \alpha_{i} \ln \left(p_{j t}^{h}\right)+\frac{1}{2} \sum_{i=1}^{n} \sum_{j=1}^{J} \gamma_{i j} \ln \left(p_{j t}^{h}\right) \ln \left(p_{s t}^{h}\right)
$$




$$
\begin{aligned}
& \ln b(p)=\prod_{i}^{n} p_{i}^{\beta_{i}} \\
& \ln \lambda(p)=\sum_{i=1}^{n} \lambda_{i} \ln \left(p_{i}\right)
\end{aligned}
$$

Where $i=1,2 \ldots, n$ shows number of goods. Applying Roy's Identity to Indirect Utility Function (Equation 2.1) yields QUAIDS in the expenditure shares form as,

$$
w_{i}=\alpha_{i}+\sum_{j=1} \gamma_{i j} \ln \left(p_{j}\right)+\beta_{i} \ln \left\{\frac{x}{a(p)}\right\}+\ln \frac{\lambda_{i}}{b(p)}\left[\ln \left\{\frac{x}{a(p)}\right\}\right]^{2}
$$

$\mathrm{w}_{i}$ depicts budget share for each food group. $\mathrm{a}_{\mathrm{i}}, \gamma_{\mathrm{i}}, \beta_{i}$, and $\lambda_{i}$ are parameters of intercept, prices, expenditure and of squared expenditure. The $\beta_{1} \ln \left\{\frac{x}{a(p)}\right\}+\ln \frac{\lambda_{i}}{b(p)}\left[\ln \left\{\frac{x}{a(p)}\right\}\right]^{2}$ measures the percentage change in real expenditures and its impact on the budget share of commodity i. Unlike AIDS, the QUAIDS model holds parameter of squared real expenditures not equal to zero $(\lambda i \neq 0)$; it allows $\lambda_{i}$ change the signs for different levels of real expenditures.

Conventional consumer theory imposes some theoretical restrictions; adding up, homogeneity, symmetry, and negative-semi-definiteness on the demand system. The QUAIDS model satisfies all restrictions, except negative-semi-definiteness. The adding up property or $\sum_{i=1}^{n} w_{i}=1$ entails the following restrictions on its parameters

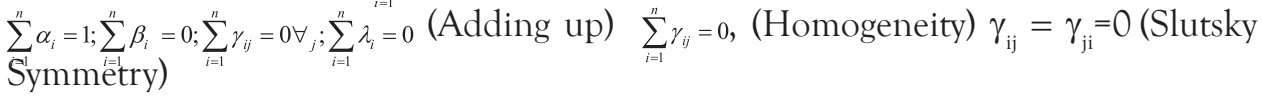

The $\alpha_{i}$ (intercept parameter) in the QUAIDS model denotes budget share item of a subsistence household at the base year prices (Pollak \& Wales, 1981). The differentiation of budget shares with respect to $\operatorname{In} x$ and $\operatorname{In} p_{j}$ yield expenditure and price elasticities:

$$
\eta_{i}=\frac{u_{i}}{w_{i}}+1
$$

The Marshallian or Uncompensated price elasticity:

$$
\eta_{i j}{ }^{U}=\frac{u_{i j}}{w_{i}}-\delta_{i j}
$$

$\delta_{i j}$ is the Kronecker delta that lies between zero and one $\left(\delta_{i j}=0\right.$ for $i \neq j$ and $\delta_{i j}$ $=1$ for $i=j$ ). The Hicksian or compensated price elasticities are calculated by using Slutsky equation as,

$$
\eta_{i j}{ }^{C}=\eta_{i j}{ }^{U}+\eta_{i}
$$

\section{Empirical Methods}

\subsection{Functional form-food demand system}

Following (Banks, Blundell, \& Lewbel, 1997; Shonkwiler \& Yen, 1999), this paper specified QUAIDS model as follows, 


$$
\begin{aligned}
& w_{i t}{ }^{h}=\alpha_{i} \psi\left(z_{i t}^{h} \xi_{i}\right)+\sum_{j=1}^{k} \gamma_{i j} \ln p_{j t}{ }^{h} \psi\left(z_{i t}^{h}{ }^{h} \xi_{i}\right)+\beta_{i} \psi\left(z_{i t}^{h} \xi_{i}\right) \ln \left[\frac{x_{t}^{h}}{a\left(p_{t}^{h}\right)}\right]+\frac{\lambda_{i}}{b\left(p_{t}^{h}\right)} \psi\left(z_{i t}^{h} \xi_{i}\right)\left\{\ln \left[\frac{x_{t}^{h}}{a\left(p_{t}^{h}\right)}\right]\right\}^{2} \\
& +\sum_{j=1}^{s} \delta_{i j} D_{j}^{h} \psi\left(z_{i t}^{h} \xi_{i}\right)+\delta_{i} \psi\left(z_{i t}^{h} \xi_{i}^{\prime}\right)+\mu_{i t}^{h}
\end{aligned}
$$

$w_{i}^{h}$ implies budget share for each of the eight food groups used in the study (denoted by $i$ ) across households $(h)$ and over panel rounds $(t)$. If all $\lambda_{i}$ terms were set to zero, the resulting model would be AIDS. This implies that AIDS nests within QUAIDS model. The squared expenditure term does not imply that the QUAIDS is superior to AIDS. It simply suggests that higher order Engel curves may exist under the tenets of utility maximization. $\alpha \mathrm{i}, \beta \mathrm{i}, \gamma_{i j}$ and $\lambda_{i}$ comply with all theoretical restrictions (adding up, homogeneity, symmetry): $\sum_{i=1}^{n} \alpha_{i}=1 ; \sum_{i=1}^{n} \beta_{i}=0 ; \sum_{i=1}^{n} \gamma_{i j}=0 \forall_{j} ; \sum_{i=1}^{n} \lambda_{i}=0$ (Adding up); $\sum_{i=1}^{n} \gamma_{i j}=0, \forall_{i}$ (Homogeneity), $\gamma_{i j}=\gamma_{j i}=0$ (Slutsky Symmetry). The price data was aggregated at the cluster level (in this paper, at the village level). Hence, households in different villages pay different prices for the purchase of similar food items. The price indices $\ln a\left(p_{t}^{h}\right)$ and $b\left(\ln p_{t}^{h}\right)$ are defined

$$
\begin{aligned}
& \ln a\left(p_{t}^{h}\right)=\alpha+\sum_{i=1}^{n} \alpha_{i} \ln \left(p_{j t}^{h}\right)+\frac{1}{2} \sum_{i=1}^{n} \sum_{j=1}^{J} \gamma_{i j} \ln \left(p_{j t}^{h}\right) \ln \left(p_{s t}^{h}\right) \\
& \text { and } \ln b\left(p_{t}^{h}\right)=\beta_{0} \prod_{i}^{n}\left(p_{i t}^{h}\right)^{\beta_{i}} \text { (11), respectively. }
\end{aligned}
$$

This paper allowed non-linearity to enter the food demand model by using squared total expenditure as an explanatory variable. $z_{k t}=\left(z_{1 t}^{h}, z_{2 t}^{h}, \ldots \ldots \ldots, z_{k t}^{h}\right)$ is a set of demographic variables (age, household size, gender, etc.) at time $t$ for the household h. Literature suggests various methods to include demographic variables to the demand system (Gorman, 1980; Lewbel, 1985; Pollak \& Wales, 1980). The methods are different in the use of scaling and translating demographic factors in the demand system (Pollak \& Wales, 1980).

Demographic Scaling involves scaling of price and quantities by household size and age composition. It can take the form of similar scaling for all goods (number of adult equivalent in the household) or different scaling (number of adult equivalent in household measured on a scale appropriate for each commodity). On the other hand, demographic translation involves using demographic factors (gender, place of residence etc.) in the subsistence parameters (usually intercept) of the demand system. Linear demographic translation of (Pollak \& Wales, 1981), which uses demographic factors as intercept shifters, is vastly employed in the empirical literature. This paper used Linear Demographic Transformation method to avoid further nonlinearities in the model. The socio-demographic variables enter the demand model through intercept. The quantity of food purchase, food consumption from own production, received as gifts and as a wage, and total expenditures on all food items (45 food items) were used, from all three rounds. All food items were grouped into eight food aggregates: cereals, pulses, meat, vegetables and fruits, milk and milk products, oil, 
sugar, and other food.

\subsection{Specification test}

(Banks et al., 1997) provided theoretical evidence (see corollary 2 in the study of (Banks et al., 1997) on page 533) that demand system, which is rank three, exactly aggregable and derived from utility maximization principle, cannot have both the coefficient on linear and quadratic expenditure terms independent of prices. This study used LM test for AIDS (nested model in QUAIDS) versus QUAIDS to determine the statistical significance of prices on the coefficient of total expenditure terms in each budget share equation as well as across the system of equations. The LM test requires the use of Modified Stone Price index (Moschini, 1995), as follows,

$$
\ln a\left(p_{t}^{h}\right) \equiv \sum_{i=1}^{n} \overline{w_{i 0}^{h}} \ln \left(p_{i t}^{h}\right)
$$

$\overline{w_{i 0}^{h}}$ is the average budget share of household $\mathrm{h}$ in the base period of commodity $i$ and $\ln a\left(p_{t}^{h}\right)$ is Translog price aggregator.

\subsection{Expenditure endogeneity}

This problem arises if household expenditure allocated to different food groups are either influenced by explanatory variables other than those included in the model or if total expenditures and budget share equations are jointly determined or both. The expenditure endogeneity is controlled in the budget share equations by introducing the control function, proposed by (Blundell \& Robin, 1999). In this paper, we added a control function to each budget share equation by following two steps. In the first step, we estimated reduced form regression (with instrumental variables). Following (Banks et al., 1997), total household expenditures (a proxy for income) and squared total household expenditures were used as instrumental variables. In the second step, we estimated the residuals from the first stage regression and included them as explanatory variables in the QUAIDS model.

\subsection{Observed zero expenditures}

In this study, the sample over three waves contains a high proportion of zero expenditure for other food, meat, milk, and oil. The higher proportion of observed zero expenditures cause error in the dependent variable; it fails to converge to its true value even in large samples. This study followed two-step estimation procedure, proposed by (Shonkwiler \& Yen, 1999), to include zero expenditure in the model. For this, it is assumed that every commodity share equation has a separate stochastic process $z_{i t}^{h}{ }^{\prime} \xi_{i}+v_{i t}$ such that the system of budget shares takes on the following form, 
$w_{i}^{h^{*}}=\int\left(p_{t}^{h}, x_{t}^{h}, \omega\right)+\mu_{i}^{h}$

If $z_{i}^{h}{ }^{\prime} \xi_{i}+v_{i t}=0$ Otherwise

$w_{i}^{h}$ is observed expenditure share of commodity $i$ for household $h$, while $x_{t}^{h}, p_{t}^{h}$ and $\omega$ are total expenditures, vector of prices and factors affecting food demand, respectively. $z_{i}^{h}$ is a set of demographic variables, $\xi_{i}$ are parameters to be estimated, $\mathrm{u}_{i t}$ and $\mathrm{v}_{i t}$ are random terms. Assuming that $\mathrm{u}_{i t}$ and $\mathrm{v}_{i t}$ are normally distributed, and have bivariate normal distribution for each commodity group.

$z_{i}^{h} ' \xi_{i}+v_{i t}$ and $w_{i}^{h}\left(p_{t}^{h}, x_{t}^{h} ; \omega\right)$ were assumed to be linearly correlated in each commodity group $i$, and between $w_{i}^{h}\left(p_{t}^{h}, x_{t}^{h} ; \omega\right) w_{j}^{h}\left(p_{t}^{h}, x_{t}^{h} ; \omega\right)$ for all $i \neq j$. Finally, the following system of expenditure shares was estimated as,

$$
w_{i}^{h}=\phi\left(z_{i}^{h} \xi_{i}\right) w_{i}^{h}\left(p_{t}^{h}, x_{t}^{h} ; \omega\right)+\delta_{i} \varphi\left(z_{i}^{h} \xi_{i}\right)+\varepsilon_{i t}^{h}
$$

$\phi\left(z_{i}^{h} \xi_{i}\right)$ and $\delta_{i} \varphi\left(z_{i}^{h} \xi_{i}\right)$ are probability density and cumulative function, respectively. Those were obtained by applying a two-step procedure. In the first step, the maximum likelihood probit regression estimate $\bar{\xi}$ of $\xi$ was obtained by using binary outcomes, if $w_{i}^{h}=0$, and if $w_{i}^{h}>0$. In the second step, $\phi\left(z_{i}^{h}{ }^{\prime} \xi_{i}\right)$ and $\delta_{i} \varphi\left(z_{i}^{h} \xi_{i}\right)$ were computed for all budget shares, and was estimated by Seemingly Unrelated Regression (SUR). After making correction, for the observed zero expenditure, the expenditure and price elasticity estimates were calculated as

$$
\begin{aligned}
& \mu_{i} \equiv \frac{\partial w_{i}^{*}}{\partial \ln x}=\phi\left(z_{i} \bar{\xi}_{i} \cdot\right)\left[\beta_{i}+\frac{2}{b(p)}\left\{\ln \left[\frac{x}{a(p)}\right]\right\}\right] \\
& u_{i j} \equiv \frac{\partial w_{i}^{*}}{\partial \ln p_{j}}=\phi\left(z_{i}, \bar{\xi}_{i}\right) \cdot .\left[\gamma_{i j}-\mu_{i}\left\{\alpha_{j}+\sum_{k=1}^{n} \gamma_{j k} \ln p_{k}\right\}-\frac{\lambda_{i} \beta_{j}}{b(p)}\left\{\ln \left[\frac{x}{a(p)}\right]\right\}^{2}\right]
\end{aligned}
$$

Where $\mathrm{p}_{\mathrm{k}}$ is the arithmetic mean, which is calculated by taking arithmetic mean of all prices in food group $k$, the conditional expenditure elasticity was computed as,

$$
\eta_{i}=\left(\frac{u_{i}}{w_{i t}^{*}}\right)+1
$$

and Marshallian or uncompensated price elasticity was calculated as,

$\eta_{i j}^{U}=\frac{u_{i}}{w_{i t}^{*}}-\delta_{i j}$

$\delta_{i j}$ is Kronecker delta, which is equal to one if $\mathrm{i}=\mathrm{j}$ or zero otherwise, the compensated or Hicksian price elasticity was calculated as

$$
\eta_{i j}^{C}=\left(\frac{u_{i}}{w_{i t}^{*}}\right)+\eta_{i} w_{i t}^{*}
$$




\subsection{Estimating changes in household welfare}

This paper measured the welfare effects of food price changes by using money metric indirect utility function or income compensation function. The money metric indirect utility function is obtained from minimum expenditure function; it signifies minimum expenditure needed by household to attain a certain utility level at the given prices (Deaton \& Muellbauer, 1980), as follows,

$$
\mathrm{E}=(\mathrm{u}, \mathrm{p})
$$

E refers to minimum expenditure needed to attain a utility level $u$ at the given vector of prices $p$. A first-order Taylor expansion with respect to prices gives an approximation of the total expenditure or income needed to compensate household for price changes and to keep utility at its previous level. This is equivalent to compensation variation (Deaton, 1989). The first-order Taylor approximation is expressed as,

$$
\Delta E \approx q \Delta p
$$

$\mathrm{q}$ implies $1 \mathrm{x} \mathrm{n}$ vector of quantities of food consumption, $\Delta p$ is a $1 \mathrm{x} \mathrm{n}$ vector of price changes, and $\mathrm{n}$ refers to a total number of food groups in the food demand system. Following (Friedman \& Levinsohn, 2001), the straightforward formulation of the expression is $\Delta E \approx \sum_{i=1}^{n} w_{i}^{h} \Delta p_{i}$,

$i$ refers to individual groups in the system of food demand, and $h$ refers to the household. $\mathrm{w}_{\mathrm{i}}$, implies a cost of commodity $\mathrm{i}$ for household $\mathrm{h}$ divided by household expenditures before price changes or base year household expenditure. Yet, the first order Taylor expansion of minimum expenditure function provides limited information on the expenditures needed to maintain utility of its previous level. In other words, the expenditure needed to attain the previous level of utility (before price changes level) increases by a smaller proportion, as equation 14 does not capture the substitution effect of relative price changes.

This paper used second-order Taylor expansion of the expenditure function,

$$
\Delta E \approx q \Delta p+\frac{1}{2} \cdot \Delta p^{T} s \Delta p
$$

$\Delta p$ and $q$ are price change and quantity vectors and $s$ is $\mathrm{n} \times \mathrm{n}$ matrix of compensated derivative of demand. In the budget share form,,

$$
\Delta \ln E \approx \sum_{i=1}^{n} w_{i}^{h} \Delta \ln p_{i}^{h}+\frac{1}{2} \sum_{i=1}^{n} \sum_{j=1}^{n} C_{i j} \Delta \ln p_{i}^{h} \Delta \ln p_{j}^{h}
$$

Where $\mathrm{C}_{i j}$ contains Slutsky derivative which is derived as: $C_{i j}=\frac{p_{i j} s_{i} p_{j}}{C^{h}}$. In $\Delta p_{i}$ is the proportionate change in prices, $\Delta \ln p_{i}=\Delta \ln p_{t}-\Delta \ln p_{t-1} \cdot C_{i j}=w_{i j} \eta_{i j} \cdot \eta_{i j}$ is Hicksian (Compensated) price elasticity of commodity group with respect to change in the price of 
commodity group $j$. The final expression for compensation variation is,

$$
\Delta \ln E \approx \sum_{i=1}^{n} w_{i}^{h} \Delta \ln p_{i}^{h}+\frac{1}{2} \sum_{i=1}^{n} \sum_{j=1}^{n} \eta_{i j} \Delta \ln p_{i}^{h} \Delta \ln p_{j}^{h}
$$

It shows that compensation variation depends on the changes in relative prices of commodities and the importance of commodity in the food basket of household. The compensation variation would be positive if food price increase caused loss in the welfare, and it would be negative if price increase yielded improvement in the welfare (Deaton, 1989; Friedman \& Levinsohn, 2001; Vu \& Glewwe, 2011).

This study used equations 14-17 to measure welfare impacts of food price changes for rural panel households during 2001-2010.

\section{Results and Discussion}

\subsection{Household characteristics: socioeconomic and demographic}

This paper used a pooled sample of $(n=3,654)$ rural households. The mean age of the head of household was 47 years, and about 50 percent of the head had attended schooling in all survey years. Average household size was 7, which is approximately equal to the national average for rural households (HIES, 2013-14). The average number of the dependents was 3.8, implying larger dependency in rural panel households. Almost half (53 percent) of the total panel rural households owned some livestock in the survey years (Table 1 )

Table 1: Socioeconomic and Demographic Characteristics of Rural Panel Households

\begin{tabular}{|c|c|}
\hline Variables & Overall Sample \\
\hline Household size & 7.05 \\
\hline Age of head & 46.06 \\
\hline Head's schooling & 49.0 \\
\hline Married head & 88.0 \\
\hline No of dependents & 3.8 \\
\hline Female headed Households & 6.0 \\
\hline Livestock Ownership & 53.0 \\
\hline
\end{tabular}

Notes: PRHS, 2001; PRHS, 2004; PPHS, 2010

\subsection{Food and non-food consumption}

The budget share of food declined between 2001 and 2004 by 1.8 percent and increased by 5.7 percent during 2004-2010. The food share was constantly the highest category in all through survey years followed by other goods and utilities (Table 
2). All nonfood aggregates showed a mixed trend (Table 2). The average household nominal income was PKR 6, 867 in 2001, PKR 7,832 in 2004 and PKR 15, 219 in 2010. The nominal income growth was about 48 percent during the span of panel years (2000-2010).

Existing literature indicates a disproportionate increase in food prices during 20042010, which caused an increase in the food expenditure by the greater proportion as compared to nonfood. At the household level, the impact of food price crisis mainly depends on the net market position of household in the production and consumption of food. It depends on relative food prices changes, price-induced wages, food share in total expenditures, and most importantly short-term coping strategies adopted at the household level (De Janvry \& Sadoulet, 2009; Deaton, 1989). Moreover, food price changes affected the welfare of the poor and the non-poor households quite differently. Unlike the non-poor, the poor households spend a relatively large proportion of their income on food, have a larger family size and have lower assets endowments to cope with temporary shocks (De Janvry \& Sadoulet, 2009).

Table 2: Mean Budget Shares of All Consumption Aggregates in Percentage

\begin{tabular}{|c|c|c|c|c|}
\hline \multirow{2}{*}{ Food Groups } & \multicolumn{3}{|c|}{ Year } & \multirow{2}{*}{ Pooled } \\
\cline { 2 - 4 } & 2001 & 2004 & 2010 & \\
\hline Food & 54.0 & 53.0 & 56.0 & 55.0 \\
\hline Clothing & 6.0 & 6.0 & 4.0 & 5.0 \\
\hline Transport & 4.0 & 3.0 & 2.0 & 2.0 \\
\hline Utilities & 11.0 & 13.0 & 12.0 & 11.0 \\
\hline Health & 7.0 & 8.0 & 7.0 & 7.0 \\
\hline Education & 3.0 & 3.0 & 4.0 & 3.0 \\
\hline Other Goods & 15.0 & 14.0 & 15.0 & 15.0 \\
\hline Total Household Expenditure & PKR 6,867 & PKR 7,832 & PKR15,219 & PKR10,197 \\
\hline
\end{tabular}

Notes: PRHS, 2001; PRHS, 2004; PPHS, 2010

This paper aggregates all food items into eight groups; cereals, pulses, meat, vegetables and fruits, milk and milk products, oil, sugar, and other food (Table 3). Groupings were used solely to economize on the estimation of food demand parameters. While making food groups, consideration was to include only those items in each group, which were more or less close substitutes of each other in that group. The assumption of perfect collinearity in the unit prices of similar food items was made in the aggregation of food items ( Lewbel, 1996; Reed, Levedahl, \& Hallahan, 2005).

In all survey years, cereals dominated over other groups in total food expenditures 
Table 3: The Food Groups and Items in Food Groups

\begin{tabular}{|c|c|}
\hline Cereals & $\begin{array}{c}\text { flour, wheat, rice, white flour, maize, buns and bread, other grains, bis- } \\
\text { cuits and cake }\end{array}$ \\
\hline Pulses & chickpeas, mung dal, masoor, mash \\
\hline Meat & beef, mutton, fish, chicken \\
\hline $\begin{array}{c}\text { Vegetables and } \\
\text { Fruits }\end{array}$ & onions, potatoes, sag, other vegetables, bananas, other fruits \\
\hline $\begin{array}{c}\text { Milk and Milk } \\
\text { Products }\end{array}$ & $\begin{array}{c}\text { fresh milk, powder milk, baby formula, yoghurt, cheese, butter, other milk } \\
\text { products }\end{array}$ \\
\hline Cooking Oil & dalda, ghee, vegetable oil \\
\hline Sugar & gur, sugar \\
\hline Other Food & egg, soft drinks, miscellaneous \\
\hline
\end{tabular}

Notes: PRHS, 2001; PRHS, 2004; PPHS, 2010

(Table 4). Its share declined by about 9 percent during 2001-2004, by 6.8 percent during 2004-2010, and by a greater percentage (18 percent) over the period (2001-2010). The persistent decline in cereals consumption shows the impact of an increase in income that enabled the household to shift to more calorie-dense food. A relatively higher share of vegetables points out that rural households consume cereals with cooked vegetables. The moderately higher milk share suggests that milk and milk-products serve as imperfect substitutes of cereals.

Table 4: Mean Budget Shares of Food Aggregates in Percentage

\begin{tabular}{|c|c|c|c|c|}
\hline \multirow{2}{*}{ Food Groups } & \multicolumn{3}{|c|}{ Average Budget Shares by Year } & \multirow{2}{*}{ Pooled } \\
\cline { 2 - 4 } & 2001 & 2004 & 2010 & \\
\hline Cereals & 32.0 & 29.0 & 27.0 & 29.0 \\
\hline Meat & 6.0 & 8.0 & 7.0 & 7.0 \\
\hline Vegetables and Fruits & 15.0 & 16.0 & 11.0 & 13.0 \\
\hline Milk and Milk Products & 23.0 & 19.0 & 22.0 & 22.0 \\
\hline Cooking Oil & 10.0 & 11.0 & 11.0 & 11.0 \\
\hline Sugar & 9.0 & 7.0 & 10.0 & 8.0 \\
\hline Pulses & 3.0 & 4.0 & 4.0 & 5.0 \\
\hline Other Food & 3.0 & 6.0 & 8.0 & 6.0 \\
\hline Mean food expenditure & PKR 3,832 & PKR 4,429 & PKR 8,490 & PKR 5,713 \\
\hline
\end{tabular}

Notes: PRHS, 2001; PRHS, 2004; PPHS, 2010 
The nominal food expenditures increased by 14 percent during 2001-2004 and by unprecedented proportion ( 94 percent) during 2004-2010 (see Table 4). Nominal and real prices of other food were the highest in all rounds followed by meat (meat carried the highest value in 2004). The cereals price (nominal) increased slightly (13.8 percent) during 2001-2004, and showed an alarming increase (154 percent) during 2004-2010. The consumption of pulses (per kilogram) showed a higher value ( 22.5 percent) during 2001-2004 and unprecedented increase (119 percent) during 2004 2010. Almost prices of all food items increased by manifold during 2004-2010 except of eggs, drinks and miscellaneous (Table 5).

Table 5: Mean Prices per Kilogram of each Food Group: Nominal prices versus Real prices

\begin{tabular}{|c|c|c|c|c|c|c|}
\hline \multirow{2}{*}{ Food Groups } & \multicolumn{3}{|c|}{ Mean Nominal prices per kg } & \multicolumn{3}{c|}{ Mean Real prices per kg } \\
\cline { 2 - 7 } & 2001 & 2004 & 2010 & 2001 & 2004 & 2010 \\
\hline Cereals & 18.80 & 21.41 & 54.39 & 17.69 & 18.01 & 23.91 \\
\hline Meat & 73.62 & 90.77 & 210.74 & 72.56 & 69.89 & 95.03 \\
\hline $\begin{array}{c}\text { Vegetables and } \\
\text { Fruits }\end{array}$ & 11.49 & 12.27 & 25.19 & 10.72 & 11.15 & 12.01 \\
\hline $\begin{array}{c}\text { Milk and Milk } \\
\text { Products }\end{array}$ & 43.12 & 50.83 & 75.49 & 40.01 & 40.73 & 44.35 \\
\hline Cooking Oil & 58.71 & 68.66 & 141.06 & 56.34 & 59.13 & 70.28 \\
\hline Sugar & 27.06 & 28.20 & 53.75 & 25.01 & 27.09 & 28.18 \\
\hline Pulses & 28.06 & 34.40 & 75.44 & 26.08 & 26.90 & 30.01 \\
\hline Other Food & 93.42 & 91.67 & 107.57 & 90.02 & 90.51 & 99.06 \\
\hline
\end{tabular}

Notes: Prices per kilogram are denominated in PKR

Literature indicates that global food price crisis and particularly unexpected surges in staple food prices during 2004-2008 affected a great majority of households in Pakistan.. The incidence of poverty, which was already widespread in rural areas, increased from 28.1 percent in 2004-05 to 32.5 percent in 2004-05 (at the food prices of 2007-08) due to increasing food price (Ul Haq et al., 2008). Moreover, the incidence of food insecurity reached to the alarming level in Sindh (48 percent) and in Punjab (33 percent) due to a substantial increase in cereal prices during 2004-08 and floods in 2010 (Friedman et al., 2011) the reduction in caloric availability at household level is measured. The analysis of calorie intake by source supports the notion that rural households were shielded from the worst effects of the crisis by their capacity to grow their own food. Compensating variation estimates suggest that the average household would need 38 percent of its total precrisis expenditure to maintain precrisis consumption levels. The impact of the food price crisis (measured as the percentage of total expenditure required to restore consumption to the precrisis level. 


\subsection{Results of specification test}

Results of the test of Lagrange Multiplier show that null hypotheses were rejected for each food budget share equation, except for cereals (p-value, 0.06) and milk ( $p$-value, 0.07 ), and for all equations $\left(x^{2}=181.33\right.$, $p$-value 0.000$)$. Likelihood Ratio test (Table 6, last panel) shows that total squared expenditures are significantly different from zero $\left(\mathrm{x}^{2}=88.14, \mathrm{p}\right.$-value 0.001$)$ in the system of equations. The results provide a justification for not using AIDS model in the present study (Table 6).

Table 6: Lagrange Multiplier Test for Nonlinearity of the Food Demand System (Pooled)

\begin{tabular}{|c|c|c|}
\hline \multicolumn{3}{|c|}{ Test Result For Individual Budget Share Equations } \\
\hline Food Groups & OLS & p-value \\
\hline Cereals & 39.5 & $(0.062)$ \\
\hline Meat & 13.4 & $(0.003)$ \\
\hline Vegetables & 29.3 & $(0.002)$ \\
\hline Milk & 41.1 & $(0.071)$ \\
\hline Cooking oil & 19.1 & $(0.003)$ \\
\hline Sugar & 13.7 & $(0.001)$ \\
\hline Pulses & 34.2 & $(0.002)$ \\
\hline Other food & 7.4 & $(0.001)$ \\
\hline \multicolumn{3}{|c|}{ Test Result for System of Budget Share Equations } \\
\hline $\mathrm{x}^{2}$ (p-value) & 181.3 & $(0.000)$ \\
\hline \multicolumn{3}{|c|}{ LR Test for Statistical Significance of Quadratic Expenditures Term } \\
\hline$x^{2}$ (P-value) & 88.14 & $(0.001)$ \\
\hline
\end{tabular}

\subsection{Expenditure and price elasticities}

This paper computed Expenditure elasticities of all food groups. The estimate of cereals (0.99) remained smaller than unity (inelastic) in the pooled sample (Table 7). It proposes that rural households largely depend on cereal consumption or treat cereals as the necessity. The result is consistent with previous studies by (Malik, Nazli, \& Whitney, 2015; Shabnam, Santeramo, Asghar, \& Seccia, 2016; Haq \& Cranfield, 2011; Haq et al., 2008). The expenditure elasticity estimates for sugar (1.03), milk (1.02), and meat (1.21) were greater than unity (elastic). It implies that a 1 percent increase in total income yielded 1.21 percent increase in meat demand for all sampled households. The result goes with the findings of previous studies by (Hayat et al., 2016; Malik, Nazli, \& Whitney, 2015) which suggested that rural households substitute calorie-dense and expensive food for staples after an increase in income in Pakistan. 
Table 7: Food Expenditure Elasticities (from QUAIDS estimation)

\begin{tabular}{|c|c|}
\hline Food Groups & Overall Sample \\
\hline Cereals & $0.99^{*}(0.004)$ \\
\hline Meat & $1.21^{*}(0.002)$ \\
\hline Vegetables & $0.99^{*}(0.001)$ \\
\hline Milk & $1.02 *(0.00)$ \\
\hline Cooking Oil & $1.03^{*}(0.01)$ \\
\hline Sugar & $1.03^{*}(0.01)$ \\
\hline Pulses & $0.87^{*}(0.04)$ \\
\hline Other Food & $0.92^{*}(0.05)$ \\
\hline
\end{tabular}

Notes: Robust Standard errors in parentheses; Statistical significance at ${ }^{* * *}<\mathrm{p}<$ $0.001,{ }^{*} \mathrm{p}<0.5,{ }^{* *} \mathrm{p}<0.10$

Marshallian (uncompensated) own and cross price-elasticities are given in Table 8. All estimates of own and cross-price elasticities are negative (as per conventional consumer theory) and are significant. Own price elasticities (compensated as well as uncompensated) for all food groups, except other food, were price inelastic in the pooled sample. The result is consistent with the finding of (Friedman et al., 2011) the reduction in caloric availability at household level is measured. The analysis of calorie intake by source supports the notion that rural households were shielded from

Table 8: Own and Cross Price Elasticity Estimates (Marshallian) in Pooled sample

\begin{tabular}{|c|c|c|c|c|c|c|c|c|}
\hline $\begin{array}{c}\text { Price } \\
\text { of } \rightarrow \\
\text { Demand } \\
\text { for } \downarrow\end{array}$ & Cereals & Meat & $\begin{array}{c}\text { Vegeta- } \\
\text { bles }\end{array}$ & Milk & Oil & Sugar & Pulses & $\begin{array}{c}\text { Other } \\
\text { food }\end{array}$ \\
\hline Cereals & $-0.91^{*}$ & $-0.31^{*}$ & $-0.58^{*}$ & $-0.56^{* *}$ & $-0.016^{*}$ & $0.19^{*}$ & $-0.031^{*}$ & 0.06 \\
\hline Meat & $0.23^{*}$ & $-0.99^{*}$ & $-0.22^{* * *}$ & $-0.23^{*}$ & $-0.37^{*}$ & 0.06 & $0.41^{*}$ & $0.03^{*}$ \\
\hline $\begin{array}{c}\text { Vegeta- } \\
\text { bles }\end{array}$ & $-0.34^{* *}$ & $-0.013^{*}$ & $-0.87^{*}$ & $0.07^{*}$ & $-0.09^{* *}$ & $0.17^{*}$ & $0.11^{*}$ & $0.09^{*}$ \\
\hline Milk & $-0.037^{*}$ & $0.029^{* *}$ & $0.041^{*}$ & $-0.94^{* *}$ & $0.16^{* *}$ & $-0.28^{*}$ & 0.09 & $0.27^{*}$ \\
\hline Oil & $-0.04^{*}$ & $0.005^{*}$ & $-0.003^{*}$ & 0.12 & $-0.68^{*}$ & 0.01 & -0.08 & -0.002 \\
\hline Sugar & $0.015^{* *}$ & $0.002^{*}$ & $0.004^{*}$ & $-0.012^{*}$ & $0.003^{*}$ & $-0.62^{*}$ & 0.004 & $-0.05^{*}$ \\
\hline Pulses & $-0.13^{*}$ & $0.14^{*}$ & 0.27 & $0.003^{*}$ & $-0.014^{*}$ & 0.006 & $-0.49^{*}$ & 0.002 \\
\hline $\begin{array}{c}\text { Other } \\
\text { Food }\end{array}$ & 0.04 & $0.002^{* *}$ & $0.04^{*}$ & 0.11 & $0.014^{*}$ & $0.17^{*}$ & 0.03 & $-1.03^{*}$ \\
\hline
\end{tabular}

Notes: Statistical significance at ${ }^{* * *}<\mathrm{p}<0.001,{ }^{*} \mathrm{p}<0.5,{ }^{* *} \mathrm{p}<0.10$ 
the worst effects of the crisis by their capacity to grow their own food. Compensating variation estimates suggest that the average household would need 38 percent of its total precrisis expenditure to maintain precrisis consumption levels. The impact of the food price crisis (measured as the percentage of total expenditure required to restore consumption to the precrisis level. Their study showed that rural households in Pakistan obtained 58 percent calories from grain and 42 percent from other food.

The cross-price elasticity (uncompensated) of cereals with pulses and of meat with vegetables indicates that that these are complementary food groups in the pooled sample in the pooled sample. Nevertheless, cereals and pulses become a substitute if households get compensation for the loss in their income emanated from an increase in the price of cereals (Table 9). A similar result holds for meat and vegetables; these are complementary goods (by uncompensated cross-price elasticity estimates), and are substitutes (as shown by the compensated cross-price elasticity estimates, Table 9). The cross-price elasticity of milk with all other products is very low and negative, suggesting the importance of the consumption of milk and milk products among rural households. Pulses, milk products, and vegetables show higher substitution effect with all other food, whereas higher complementary effect is present in the relationship of meat and oil with all other goods.

Table 9: Own and Cross Price Elasticity Estimates (Hicksian) in Pooled sample

\begin{tabular}{|c|c|c|c|c|c|c|c|c|}
\hline $\begin{array}{c}\text { Price } \\
\text { of } \rightarrow \\
\text { Demand } \\
\text { for } \downarrow\end{array}$ & Cereals & Meat & $\begin{array}{c}\text { Vegeta- } \\
\text { bles }\end{array}$ & Milk & Oil & Sugar & Pulses & Other \\
\hline Cereals & $-0.86^{*}$ & $-0.51^{*}$ & $-0.37^{*}$ & $0.49^{*}$ & $-0.013^{*}$ & $0.11^{*}$ & $0.022^{* *}$ & 0.04 \\
\hline Meat & $0.14^{*}$ & $-0.67^{*}$ & $0.16^{* *}$ & $0.21^{* *}$ & $-0.28^{*}$ & $0.03^{*}$ & $0.33^{*}$ & 0.02 \\
\hline $\begin{array}{c}\text { Vegeta- } \\
\text { bles }\end{array}$ & $-0.21^{*}$ & $-0.001^{*}$ & $-0.43^{*}$ & $-0.05^{*}$ & $-0.04^{*}$ & $0.10^{*}$ & $0.08^{*}$ & $0.08^{*}$ \\
\hline Milk & $0.021^{*}$ & $0.009^{*}$ & $0.031^{*}$ & $-0.78^{* *}$ & $-0.12^{*}$ & $-0.22^{*}$ & 0.05 & $0.23^{*}$ \\
\hline Oil & $-0.03^{*}$ & $0.003^{*}$ & $-0.002^{*}$ & 0.08 & $-0.63^{*}$ & 0.009 & -0.005 & $-0.001^{*}$ \\
\hline Sugar & $0.013^{*}$ & $0.001^{*}$ & $0.005^{*}$ & $-0.010^{*}$ & $0.002^{*}$ & $-0.37^{*}$ & 0.002 & $-0.03^{*}$ \\
\hline Pulses & $0.10^{*}$ & $0.12^{* *}$ & 0.21 & $0.001^{*}$ & $-0.013^{*}$ & $0.004^{*}$ & $-0.37^{*}$ & 0.001 \\
\hline $\begin{array}{c}\text { Other } \\
\text { Food }\end{array}$ & 0.02 & $0.001^{* *}$ & $0.03^{*}$ & 0.09 & $0.012^{*}$ & $0.15^{*}$ & 0.02 & $-0.60^{*}$ \\
\hline
\end{tabular}

Notes: Statistical significance at ${ }^{* *}<p<0.001,{ }^{*} p<0.5,{ }^{* *} p<0.10$ 


\subsection{Welfare effects of food price changes}

Following (Friedman \& Levinsohn, 2001), we measured money metric loss in utility was computed for the increase in food prices (termed as compensation variation) in the static framework. We also estimated dynamic welfare effects of real food price changes, using estimates of the Hicksian price elasticity and household budget shares (see Equation 14). Rural households needed a 28 percent increase in food expenditures and 26 percent increase in total expenditures to keep the welfare at its previous level or unchanged (the year 2001), Table 10. The estimate of dynamic welfare impact was smaller (22 percent) than static welfare (26 percent).

Table 10: Welfare Impacts of Food Price Changes (Pooled Sample)

\begin{tabular}{|c|c|}
\hline $\begin{array}{c}\text { First Order Welfare Effect as Proportion of } \\
\text { Food Expenditures }\end{array}$ & $\begin{array}{c}\text { First Order Welfare Effect as Proportion of } \\
\text { Total Household Expenditures }\end{array}$ \\
\hline $0.28(0.002)$ & $0.26(0.001)$ \\
\hline $\begin{array}{c}\text { Second Order Welfare Effect as Proportion of } \\
\text { Food Expenditures }\end{array}$ & $\begin{array}{c}\text { Second Order Welfare effect as Proportion of } \\
\text { Total Household Expenditures }\end{array}$ \\
\hline $0.29(0.003)$ & $0.22(0.004)$ \\
\hline
\end{tabular}

Notes: Standard errors are in parentheses

A study by (Friedman et al., 2011) the reduction in caloric availability at household level is measured. The analysis of calorie intake by source supports the notion that rural households were shielded from the worst effects of the crisis by their capacity to grow their own food. Compensating variation estimates suggest that the average household would need 38 percent of its total precrisis expenditure to maintain precrisis consumption levels. The impact of the food price crisis (measured as the percentage of total expenditure required to restore consumption to the precrisis level showed adverse implications of food price crises (2007-08) for all households but more severe for poor and urban households. Their research findings pointed out that food price crisis of 2007-08 widened the income gap between the poor and the non-poor, increased overall poverty and brought down per capita calorie availability in Pakistan. The urban household needed compensation in their expenditure by at least 35 percent whereas urban poor required 45 percent to maintain welfare at its pre-crisis level.

\subsection{Welfare effects of food price changes by commodity groups}

Following the methodology given by (Friedman et al., 2011), the reduction in caloric availability at household level is measured. The analysis of calorie intake by source supports the notion that rural households were shielded from the worst effects 
of the crisis by their capacity to grow their own food. Compensating variation estimates suggest that the average household would need 38 percent of its total precrisis expenditure to maintain precrisis consumption levels. The impact of the food price crisis (measured as the percentage of total expenditure required to restore consumption to the precrisis level, we estimated compensation variation for each food group as a proportion of total household expenditures. For the calculation, we used mean budget share and magnitude of changes in the real price of each food group over 2001-2010. The food price changes influenced consumption of cereals, meat, pulses, and cooking oil significantly; the price effect was more severe for cereals and meat (PRHS, 2001; PRHS, 2010). In the pooled sample, households needed 22.3 percent additional money to keep consumption of cereals at the previous level (year-2001) and 12.5 percent additional income to compensate losses resulting from changes in the price of meat (Table 11).

Table 11: Welfare Impact of Real Food Price Changes by Commodity Groups

\begin{tabular}{|c|c|}
\hline Commodities & Pooled Sample \\
\hline Cereals & 22.3 \\
\hline & $(0.001)$ \\
\hline Meat & 12.5 \\
\hline & $(0.002)$ \\
\hline Vegetables & 6.5 \\
\hline & $(0.000)$ \\
\hline Milk products & 2.7 \\
\hline & $(0.001)$ \\
\hline Cooking oil & 10.14 \\
\hline & $(0.002)$ \\
\hline Sugar & 4.9 \\
\hline & $(0.002)$ \\
\hline Pulses & 8.10 \\
\hline & $(0.000)$ \\
\hline Other food & 3.5 \\
\hline
\end{tabular}

Notes: Robust Standard errors in parentheses

\section{Conclusion and Policy Recommendation}

The present study adds to the empirical evidence on the use of parametric methods for the identification of the rank of food demand system in developing countries. This study used a balanced panel data, which helps to avoid issues of sample selection 
and attrition bias. Lagrange Multiplier test used in the study identified rank-three (QUAIDS) food demand system for rural panel households in Pakistan. The full food demand system was estimated for eight food groups ( cereals, meat, vegetables, milk, and milk products, cooking oil, sugar, pulses and other food) using NLSUR in Stata 12. The estimation was undertaken after accounting for endogeneity (using control function proposed by (Shonkwiler \& Yen, 1999) and the problem of zero expenditure following (Blundell \& Robin, 1999). The welfare analysis produced in this study with the use of parameters of QUAIDS (appropriately specified) provides richer information (measures of static and dynamic welfare effects) as compared to the existing literature.

Only two studies have provided estimates of the welfare effects of food price changes in Pakistan at the aggregate level. (Friedman et al., 2011) used repeated cross-sectional data (2005-06, 2007-08 and 2010 (January-June)) and estimated compensation variation for rural and urban households. Their paper did not use theoretically consistent demand model and did not include results for welfare impacts of food prices with the substitution effect. Their research findings showed that rural and urban households needed 39.1 percent and 36 percent increase in income (without substitution effect), respectively, to maintain utility at the pre-crisis level (2005-06). Another study by (Haq et al., 2008) used cross-sectional data set, HIES (2004-05), and estimated welfare effect of counterfactual price changes for the poor and the nonpoor in urban and rural samples. Their study found that counterfactual food price changes increased rural poverty by 32.5 percent and urban poverty by 44.6 percent.

This paper used first and second order Taylor approximation to measure static (without substitution in goods) and dynamic (with substitution in goods) welfare effects of real food price changes for all households. This kind of analysis provides the groundwork for policy formulation on food security by answering some relevant policy questions, for instance, how and why a given welfare program or reduction in price fails to compensate a particular group (net buyer or net seller) of rural households. The findings from this study showed that if people are provided with access to close substitutes of food commodities, which they consume, the losses from food prices increase could be reduced significantly.

Results from expenditure and price elasticities maybe used to shed light on the welfare effects of price and income changes. The cereals are own price inelastic (uncompensated and compensated) in the pooled sample $(-0.91$ and -0.86$)$. This infers that increase in cereals price is directly proportional to increase in total expenditure of rural households. The policymakers can use these findings to make well-informed decisions, and use prices as an instrument for stabilizing household welfare. 
The study computed compensation variation, money needed to keep welfare at the previous level, of real food price changes for pooled samples. Results showed that static welfare effects (first-order welfare effects) were larger than dynamic (second-order welfare effects). Moreover, estimates of welfare impacts by commodity groups reveal that rural households needed the highest compensation for changes in cereal prices, which calls for adoption of commodity specific social safety measures.

These results relating to welfare losses by commodity groups are important for policymakers. They need to take into account the importance of cereal consumption (as suggested by the analysis) in rural areas to set the support price for cereals. Currently, the consumer protection is guaranteed by setting the domestic cereal prices lower than international prices, which largely benefits urban consumers and discourages the supply of cereals production in the long term. Therefore, the government should take twofold measures; increase domestic cereal prices to international levels and extend social safety nets to households, who are more vulnerable.

\section{References}

Ahmad, E., Ludlow, S., \& Stern, N. (1988). Demand response in Pakistan: A modification of the Linear Expenditure System for 1976. Pakistan Development Review, 27(3), 93-308.

Alderman, H. (1988). Estimates of consumer price response in Pakistan using market prices as Data. Pakistan Development Review, 27(2), 89-107.

Ali, M. S. (1985). Household consumption and saving behaviour in Pakistan: An application of the Extended Expenditure System. Pakistan Development Review, 24(1), 23-37.

Banks, J., Blundell, R., \& Lewbel, A. (1997). Quadratic Engel curves and consumer demand. Review of Economics and Statistics, 79(4), 527-539.

Barten, A. P. (1964). Consumer demand functions under conditions of almost additive preferences. Econometrica, 32(1-2), 1-38.

Bhalotra, S., \& Attfield, C. (1998). Intrahousehold resource allocation in rural Pakistan: A semiparametric analysis. Journal of Applied Econometrics, 13(5), 463-480.

Blundell, R., \& Robin, J. M. (2000). Latent separability: Grouping goods without weak separability. Econometrica, 68(1), 53-84.

Burki, A. (1997). Estimating consumer preferences for food, using time series data of Pakistan. Pakistan Development Review, 36(2), 131-152.

Christensen, L. R., Jorgenson, D. W., \& Lau, L. J. (1975). Transcendental logarithmic utility functions. The American Economic Review, 65(3), 367-83.

De Janvry, A., \& Sadoulet, E. (2009). The impact of rising food prices on household welfare in India. working paper. 
Retrieved from https://gspp.berkeley.edu/assets/uploads/research/pdf/IndianFoodPricesMar09.pd De Janvry, A., \& Sadoulet, E. (2010). The global food crisis and Guatemala: What crisis and for whom? World Development, 38(9), 1328-1339.

Deaton, A. (1989). Rice prices and Income distribution in Thailand: A non-parametric analysis. The Economic Journal, 99(394), 1-37.

Deaton, A., \& Muellbauer, J. (1980). An almost ideal demand system. The American Economic Review, $70(3), 312-326$.

Friedman, J., Hong, S. Y., \& Hou, X. (2011). The Impact of the Food Price crisis on consumption and caloric availability in Pakistan : Evidence from repeated cross-sectional and panel data. Retrieved from: http:// iteresources.worldbank.org/healthnutritionandpopulation/Resources/281627-1095698140167/ foodpricecrisispak.pdfFriedman, J., \& Levinsohn, J. A. (2001). The distributional impacts of Indonesia's financial crisis on household welfare: A rapid response methodology (NBR working paper series No. 8564). Retrieved from: https://doi.org/10.2139/ssrn.285154

G. M. Arif. (2012). Pakistan Panel Household Survey Sample Size, attrition and socio-demographic dynamics (Poverty and Social Dynamic Paper Series- 1). Islamabad. Retrieved from:

https://pide.org.pk/pdf/PSDPS/PSDPS\%20Paper-1.pdf

Gorman, W, M. (1980). Tricks with utility functions "Essays in economic analysis”. M. Artis and R. Nobay eds. Cambridge: Cambridge University Press.

Gould, B. W., \& Villarreal, H. J. (2006). An assessment of the current structure of food demand in urban China. Agricultural Economics, 34(1), 1-16.

Hayat, N., Hussain, A., \& Yousaf, H. (2016). Food demand in Pakistan: Analysis and projections. South Asia Economic Journal, 17(1), 94-113.

Heien, D., \& Wessells, C. R. (1990). Demand systems estimation with microdata: A censored regression approach. Journal of Business and Economic Statistics, 8(3), 365-371.

Jorgenson, D. W., \& Slesnick, D. T. (1987). Aggregate consumer behavior and household equivalence scales. Journal of Business and Economic Statistics, 5(2), 219-232.

Kurosaki, T. (2006). Consumption vulnerability to risk in rural Pakistan. Journal of Development Studies, 42(1), 70-89.

Kurosaki, T., \& Khan, H. (2006). Human capital, productivity, and stratification in rural Pakistan. Review of Development Economics, 10(1), 116-134.

Laurits, R., Christensen, Dale, W., Jorgenson, L. J., \& Lau. (1975). Transcendental logarithmic utility functions. The American Economic Review, 65(3), 367-383.

Lewbel, A. (1996). Aggregation without separability: A generalized composite commodity theorem. 
American Economic Review, 86(3), 524-543.

Lewbel, A. (1991). The rank of demand dystems: Theory and nonparametric estimation. Econometrica, 94, 979-1000.

Malik, S. J., Nazli, H., \& Whitney, E. (2015). Food consumption patterns and implications for poverty reduction in Pakistan. Pakistan Development Review, 54(4), 651-670.

McCulloch, N., \& Baulch, B. (2000). Simulating the impact of policy upon chronic and transitory poverty in rural Pakistan. Journal of Development Studies, 36(6), 100-130.

Meenakshi, J. V., \& Ray, R. (1999). Regional differences in India's food expenditure pattern: A complete demand systems approach. Journal of International Development, 11(1), 47-74.

Moschini, G. (1995). Units of measurement and the stone Index in demand system estimation. American Journal of Agricultural Economics, 77(1), 63-68.

Pollak, R. A., \& Wales, T. J. (1969). Estimation of the linear expenditure system. Econometrica, 37(4), 403-410.

Pollak, R. A., \& Wales, T. J. (1981). Demographic variables in demand analysis. Econometrica, 49(6), 1533-1551.

Reed, A. J., Levedahl, J. W., \& Hallahan, C. (2005). The generalized composite commodity theorem and food demand estimation. American Journal of Agricultural Economics, 87(1), 28-37.

Shabnam, N., Santeramo, F. G., Asghar, Z., \& Seccia, A. (2016). The impact of food price crises on the demand for nutrients in Pakistan. Journal of South Asian Development, 11(3), 305-327.

Shamim, F., \& Ahmad, E. (2007). Understanding household consumption patterns in Pakistan. Journal of Retailing and Consumer Services, 14(2), 150-164.

Shonkwiler, J. S., \& Yen, S. T. (1999). Two-step estimation of a censored system of equations. American Journal of Agricultural Economics, 81(4), 972-982.

Siddiqui, R. (1982). An analysis of consumption pattern in Pakistan. Source: The Pakistan Development Review The Pakistan Development Review, 21(4), 275-296.

Stone, R. (1954). Linear expenditure systems and demand Analysis: An application to the pattern of British demand. The Economic Journal, 64(255), 511-527.

Theil, H. (1965). The information approach to Demand analysis. Econometrica, 33(1), 67-87.

Haq, Z., \& Cranfield, J. (2011). Household food demand in Pakistan: Does demand specification matter? African Journal of Business Management, 5(26), 1-16.

Haq, Z., Nazli, H., \& Meilke, K. (2008). Implications of high food prices for poverty in Pakistan. Agricultural Economics, 39(SUPPL. 1), 477-484. 
Vu, L., \& Glewwe, P. (2011). Impacts of rising food prices on poverty and welfare in Vietnam. Journal of Agricultural and Resource Economics, 36(1), 79-95.

Zahor Ul Haq, Hina Nazli, Karl Meilke, Muhammad Ishaq, Amjad Khattak, Arshad H.Hashmi, F. U. R. (2011). Food demand patterns in Pakistani Punjab. Serhad Journal of Agriculture, 27(2), 305-311. 


\section{APPENDIX}

Table 1: Estimated Parameters from QUAIDS (Pooled sample)

\begin{tabular}{|c|c|c|c|c|c|c|c|c|}
\hline $\begin{array}{l}\text { Vari- } \\
\text { ables }\end{array}$ & Cereals & Meat & $\begin{array}{l}\text { Vegeta- } \\
\text { bles }\end{array}$ & Milk & $\begin{array}{c}\text { Cooking } \\
\text { Oil }\end{array}$ & Sugar & Pulses & $\begin{array}{l}\text { Other } \\
\text { food }\end{array}$ \\
\hline \multirow{2}{*}{$\begin{array}{l}\text { Con- } \\
\text { stant }\end{array}$} & & 0.1233 & 0.0877 & 0.3221 & 0.0221 & 0.0198 & 0.2981 & 0.5321 \\
\hline & $(0.001)$ & $(0.012)$ & $(0.003)$ & $(0.0231)$ & $(0.011)$ & $(0.001)$ & $(0.021)$ & (0.004 \\
\hline \multirow{2}{*}{$\begin{array}{l}\text { Price of } \\
\text { cereals }\end{array}$} & 0.0271 & -0.0192 & -0.0132 & -0.0422 & -0.005 & -0.0019 & -0.0021 & 0.0026 \\
\hline & $(0.001)$ & $(0.003)$ & $(0.001)$ & $(0.002)$ & $(0.001)$ & $(0.000)$ & (0.001) & $(0.001)$ \\
\hline \multirow{2}{*}{$\begin{array}{c}\text { Price of } \\
\text { meat }\end{array}$} & -0.0192 & 0.0691 & -0.0030 & 0.0164 & -0.0174 & -0.0041 & -0.0061 & -0.0072 \\
\hline & $(0.003)$ & $(0.001)$ & $(0.001)$ & $(0.001)$ & $(0.001)$ & $(0.001)$ & $(0.001)$ & $(0.001)$ \\
\hline \multirow{2}{*}{$\begin{array}{c}\text { Price of } \\
\text { vegetable }\end{array}$} & -0.0133 & -0.0030 & 0.0591 & 0.0164 & -0.0192 & 0.0043 & -0.0041 & -0.0079 \\
\hline & $(0.001)$ & $(0.001)$ & $(0.001)$ & $(0.001)$ & $(0.001)$ & $(0.000)$ & $(0.001)$ & $(0.001)$ \\
\hline \multirow{2}{*}{$\begin{array}{l}\text { Price of } \\
\text { milk }\end{array}$} & -0.0422 & 0.0164 & 0.0164 & 0.0665 & 0.0592 & -0.0148 & 0.0091 & -0.0067 \\
\hline & $(0.002)$ & $(0.001)$ & $(0.001)$ & $(0.002)$ & $(0.001)$ & $(0.003)$ & $(0.001)$ & $(0.002)$ \\
\hline \multirow{2}{*}{$\begin{array}{c}\text { Price of } \\
\text { cooking } \\
\text { oil }\end{array}$} & -0.0051 & -0.0174 & -0.0192 & 0.0592 & 0.0491 & -0.0061 & -0.0219 & -0.0233 \\
\hline & $(0.001)$ & $(0.001)$ & $(0.001)$ & $(0.001)$ & $(0.001)$ & $(0.001)$ & $(0.001)$ & $(0.001)$ \\
\hline \multirow{2}{*}{$\begin{array}{l}\text { Price of } \\
\text { sugar }\end{array}$} & -0.0019 & -0.004 & 0.0043 & -0.0148 & -0.0061 & 0.0231 & -0.004 & -0.0034 \\
\hline & $(0.000)$ & $(0.001)$ & $(0.000)$ & $(0.003)$ & $(0.001)$ & $(0.002)$ & $(0.001)$ & $(0.001)$ \\
\hline \multirow{2}{*}{$\begin{array}{l}\text { Price of } \\
\text { pulses }\end{array}$} & -0.0021 & & & & -0.0219 & & & \\
\hline & $(0.001)$ & $(0.001)$ & $(0.001)$ & $(0.001)$ & $(0.001)$ & $(0.001)$ & $(0.001)$ & $(0.001)$ \\
\hline \multirow{2}{*}{$\begin{array}{c}\text { Price of } \\
\text { other } \\
\text { food }\end{array}$} & 0.0026 & -0.0074 & -0.0079 & -0.0067 & -0.0233 & -0.0034 & -0.0023 & 0.0291 \\
\hline & $(0.001)$ & $(0.002)$ & $(0.001)$ & $(0.002)$ & $(0.001)$ & $(0.001)$ & $(0.001)$ & $(0.002)$ \\
\hline \multirow{2}{*}{$\begin{array}{l}\text { food } \\
\text { expendi- } \\
\text { ture }\end{array}$} & -0.0441 & 0.0134 & -0.0181 & -0.0341 & 0.0286 & -0.0113 & -0.0144 & 0.0124 \\
\hline & $(0.001)$ & $(0.002)$ & $(0.002)$ & $(0.002)$ & $(0.002)$ & $(0.001)$ & $(0.001)$ & $(0.001)$ \\
\hline \multirow{2}{*}{$\begin{array}{c}\text { Food } \\
\text { expen- } \\
\text { diture } \\
\text { squared }\end{array}$} & -0.0054 & -0.0036 & -0.0002 & 0.0028 & -0.0011 & & & 0.0022 \\
\hline & $(0.001)$ & $(0.001)$ & $(0.001)$ & & $(0.001)$ & $(0.001)$ & $(0.001)$ & $(0.001)$ \\
\hline \multirow{2}{*}{$\begin{array}{l}\text { Depen- } \\
\text { dency }\end{array}$} & 0.0210 & -0.0035 & 0.0021 & 0.0451 & 0.0031 & 0.0024 & 0.0113 & 0.0021 \\
\hline & $(0.001)$ & $(0.001)$ & $(0.001)$ & $(0.001)$ & $(0.000)$ & $(0.001)$ & $(0.003)$ & $(0.001)$ \\
\hline
\end{tabular}




\begin{tabular}{|c|c|c|c|c|c|c|c|c|}
\hline $\begin{array}{c}\text { Live- } \\
\text { stock } \\
\text { owner- } \\
\text { ship }\end{array}$ & 0.0321 & 0.0102 & 0.0041 & 0.0024 & 0.0061 & 0.0014 & -0.0036 & -0.0023 \\
\cline { 2 - 9 } & $(0.001)$ & $(0.002)$ & $(0.001)$ & $(0.001)$ & $(0.001)$ & $(0.001)$ & $(0.001)$ \\
\hline $\begin{array}{c}\text { Educa- } \\
\text { tion }\end{array}$ & 0.0058 & -0.0028 & -0.0331 & 0.0291 & 0.0051 & 0.0016 & 0.0121 & 0.0113 \\
\cline { 2 - 9 } & $(0.001)$ & $(0.001)$ & $(0.002)$ & $(0.003)$ & $(0.001)$ & $(0.001)$ & $(0.001)$ & $(0.001)$ \\
\hline $\begin{array}{c}\text { Age } \\
\text { of the } \\
\text { house- } \\
\text { hold } \\
\text { head }\end{array}$ & 0.0012 & 0.0018 & 0.0022 & -0.0021 & 0.0044 & 0.0011 & 0.0031 & 0.0042 \\
\cline { 2 - 9 } & $(0.001)$ & $(0.000)$ & $(0.001)$ & $(0.001)$ & $(0.001)$ & $(0.001)$ & $(0.001)$ & $(0.001)$ \\
\hline $\begin{array}{c}\text { House- } \\
\text { hold size }\end{array}$ & 0.0082 & -0.0012 & 0.0051 & 0.0311 & 0.0011 & 0.0026 & 0.0019 & -0.0015 \\
\cline { 2 - 9 } & $(0.001)$ & $(0.000)$ & $(0.001)$ & $(0.001)$ & $(0.001)$ & $(0.003)$ & $(0.000)$ & $(0.001)$ \\
\hline
\end{tabular}

Table 2: Cross Price Elasticity Estimates (Marshallian) For All Households

\begin{tabular}{|c|c|c|c|c|c|c|c|c|}
\hline $\begin{array}{c}\text { Com- } \\
\text { modity }\end{array}$ & Cereals & Meat & $\begin{array}{c}\text { Vegeta- } \\
\text { bles }\end{array}$ & Milk & Oil & Sugar & Pulses & Other \\
\hline Cereals & -0.91 & -0.31 & -0.58 & -0.56 & -0.016 & 0.19 & -0.031 & 0.06 \\
\hline Meat & 0.23 & -0.99 & -0.22 & -0.23 & -0.37 & 0.06 & 0.41 & 0.03 \\
\hline $\begin{array}{c}\text { Vegeta- } \\
\text { bles }\end{array}$ & -0.34 & -0.013 & -0.87 & 0.07 & -0.09 & 0.17 & 0.11 & 0.09 \\
\hline Milk & -0.037 & 0.029 & 0.041 & -0.94 & 0.16 & -0.28 & 0.09 & 0.27 \\
\hline Oil & -0.04 & 0.005 & -0.003 & 0.12 & -0.68 & 0.01 & -0.08 & -0.002 \\
\hline Sugar & 0.015 & 0.002 & 0.004 & -0.012 & 0.003 & -0.62 & 0.004 & -0.05 \\
\hline Pulses & -0.13 & 0.14 & 0.27 & 0.003 & -0.014 & 0.006 & -0.49 & 0.002 \\
\hline $\begin{array}{c}\text { Other } \\
\text { Food }\end{array}$ & 0.04 & 0.002 & 0.04 & 0.11 & 0.014 & 0.17 & 0.03 & -1.03 \\
\hline
\end{tabular}


Table 3: Cross Price Elasticity Estimates (Hicksian) For All Households

\begin{tabular}{|c|c|c|c|c|c|c|c|c|}
\hline $\begin{array}{c}\text { Com- } \\
\text { modity }\end{array}$ & Cereals & Meat & $\begin{array}{c}\text { Vegeta- } \\
\text { bles }\end{array}$ & Milk & Oil & Sugar & Pulses & Other \\
\hline Cereals & -0.86 & -0.51 & -0.37 & 0.49 & -0.013 & 0.11 & 0.022 & 0.04 \\
\hline Meat & 0.14 & -0.67 & 0.16 & 0.21 & -0.28 & 0.03 & 0.33 & 0.02 \\
\hline $\begin{array}{c}\text { Vegeta- } \\
\text { bles }\end{array}$ & -0.21 & -0.001 & -0.43 & -0.05 & -0.04 & 0.10 & 0.08 & 0.08 \\
\hline Milk & 0.021 & 0.009 & 0.031 & -0.78 & -0.12 & -0.22 & 0.05 & 0.23 \\
\hline Oil & -0.03 & 0.003 & -0.002 & 0.08 & -0.63 & 0.009 & -0.005 & -0.001 \\
\hline Sugar & 0.013 & 0.001 & 0.005 & -0.010 & 0.002 & -0.37 & 0.002 & -0.03 \\
\hline Pulses & 0.10 & 0.12 & 0.21 & 0.001 & -0.013 & 0.004 & -0.37 & 0.001 \\
\hline $\begin{array}{c}\text { Other } \\
\text { Food }\end{array}$ & 0.02 & 0.001 & 0.03 & 0.09 & 0.012 & 0.15 & 0.02 & -0.60 \\
\hline
\end{tabular}


